\title{
Reduced serum vitamin D concentrations in healthy early-lactation dairy cattle
}

\author{
S. J. Holcombe, ${ }^{1}$ L. Wisnieski, J. Gandy, B. Norby, and L. M. Sordillo \\ Department of Large Animal Clinical Sciences, College of Veterinary Medicine, Michigan State University, East Lansing 48824
}

\begin{abstract}
Cattle obtain vitamin D by ingestion or cutaneous exposure to UV light. Dairy cattle diets are frequently supplemented with vitamin D to compensate for limited sun exposure or during times of increased metabolic demands, such as the periparturient period, to maintain calcium homeostasis. Whether housing and supplemental vitamin D practices supply adequate amounts of vitamin D to optimally support the transition from gestation to lactation in dairy cattle is unknown. Our objective was to determine how serum vitamin $\mathrm{D}$ concentrations of dairy cows change with season, age, parity, and stage of lactation. Clinically healthy cows $(\mathrm{n}=183)$ from 5 commercial dairies were enrolled in the study. Serum samples were collected at dry off, within $7 \mathrm{~d}$ of entering the close-up group, and within $7 \mathrm{~d}$ after calving (calving +7 ). Vitamin D status was determined by measuring serum 25-hydroxyvitamin $\mathrm{D}[25(\mathrm{OH}) \mathrm{D}]$ by radioimmunoassay. We performed repeated-measures mixed-effects linear regression to determine the effects of season, age, parity, and lactation stage (dry off, close-up, and calving +7 ) on 25(OH)D concentrations in serum. Bivariable analysis indicated that parity, age, and season were not associated with serum $25(\mathrm{OH}) \mathrm{D}$ concentrations. Sample period affected $25(\mathrm{OH}) \mathrm{D}$ concentrations, with the highest $25(\mathrm{OH})$ D levels at dry off $(99.7 \pm 1.9 \mathrm{ng} / \mathrm{mL})$ followed by close up $(93.8 \pm 2.1 \mathrm{ng} / \mathrm{mL})$, with the lowest levels at calving $+7(82.6 \pm 1.7 \mathrm{ng} / \mathrm{mL})$. These data showed a large depletion of $25(\mathrm{OH}) \mathrm{D}$ in dairy cattle postpartum compared with late prepartum, although the biological significance of this change in these healthy cattle is unclear. Consumption of serum 25(OH)D by immune system functions and calcium homeostasis in early lactation likely caused the reduction in serum $25(\mathrm{OH})$ $\mathrm{D}$ concentrations after calving. These results suggest
\end{abstract}

Received July 21, 2017.

Accepted October 8, 2017.

${ }^{1}$ Corresponding author: Holcomb6@cvm.msu.edu that determining whether serum $25(\mathrm{OH}) \mathrm{D}$ concentrations are associated with the incidence of transition period disease is an appropriate next step. Assessing the effects of enhanced vitamin D supplementation of cows in early lactation on postpartum diseases may be warranted.

Key words: 25-hydroxyvitamin D, dairy cattle, transition period

\section{INTRODUCTION}

Dietary micronutrients are crucial for enhanced immune cell functions and improved production efficiency of transition dairy cows (Spears and Weiss, 2008; Sordillo, 2016). Vitamin D is essential for skeletal development and calcium homeostasis, but current evidence suggests that vitamin D also plays an important role in optimizing immune cell functions (Adams and Hewison, 2008). Vitamin D signaling in immune cells improved some indices of innate immunity and suppressed some proinflammatory measures of adaptive immunity in cattle (Nelson et al., 2010, 2012). Moreover, vitamin D improved disease resistance in models of chronic inflammatory-based diseases and reproductive disorders in cattle (Téllez-Pérez et al., 2012; Girard et al., 2015). Infusion of vitamin D into infected mammary gland quarters enhanced local immune function, decreased colonization by mastitis-causing bacteria, and reduced SCC in milk compared with untreated cows (Lippolis et al., 2011). These data collectively support the premise that vitamin $\mathrm{D}$ improves dairy cattle immunity and may be an important micronutrient essential to preventing health disorders in dairy cows.

Dairy cattle obtain vitamin $\mathrm{D}$ from ingestion of vitamin $\mathrm{D}_{3}$ supplements, or following UV light exposure from sunlight, or by consuming vitamin $\mathrm{D}_{2}$ from plant fungi in forages (Horst et al., 1994; Hymøller and Jensen, 2012). Cattle metabolize both vitamin $\mathrm{D}_{2}$ and vitamin $\mathrm{D}_{3}$ but preferentially utilize vitamin $\mathrm{D}_{3}$ (Horst et al., 1994). Vitamin $D_{3}$ is readily metabolized to 25-hydroxyvitamin D $\left[\mathbf{2 5}(\mathbf{O H}) \mathbf{D}_{3}\right]$ by 25 -hydroxylases in the liver and is the major circulating form of vitamin $\mathrm{D}$ in cattle. The active metabolite, 1,25-dihydroxyvita- 
min $\mathrm{D}_{3}\left[\mathbf{1}, \mathbf{2 5}(\mathbf{O H})_{2} \mathbf{D}_{3}\right]$ is formed by $1 \alpha$-hydroxylation of $25(\mathrm{OH}) \mathrm{D}_{3}$ (Horst et al., 1994). The conversion of $25(\mathrm{OH}) \mathrm{D}_{3}$ to $1,25(\mathrm{OH})_{2} \mathrm{D}_{3}$ is tightly regulated in the kidney by parathyroid hormone (PTH) and locally by immune cells responding to immune signals (Horst et al., 1994; Adams and Hewison, 2008).

Dairy cattle typically receive dietary vitamin $\mathrm{D}_{3}$ supplementation to maintain consistent concentrations of $25(\mathrm{OH}) \mathrm{D}$ (the lack of subscript indicates $\mathrm{D}_{2}$ and $\mathrm{D}_{3}$ ) in the blood. The National Research Council recommends $21,000 \mathrm{IU} / \mathrm{d}$ of vitamin D for dairy cows to maintain serum 25(OH)D concentrations between 20 and $50 \mathrm{ng} /$ $\mathrm{mL}$ and support calcium homeostasis (NRC, 2001). Supplementation is necessary because the vitamin $D_{2}$ content of forages is inconsistent and vitamin $\mathrm{D}_{2}$ is less potent and effective at maintaining serum $25(\mathrm{OH})$ $\mathrm{D}$ concentrations compared with vitamin $\mathrm{D}_{3}$ (Horst et al., 1994). Exposure to UV light from sunlight is affected by season (Hymøller and Jensen, 2010, 2012) and husbandry. Many lactating cattle are housed indoors, limiting endogenous vitamin $\mathrm{D}_{3}$ production and making diet the major source of vitamin $\mathrm{D}$ in these cows.

The concentrations of $25(\mathrm{OH}) \mathrm{D}$ in blood that correspond to optimal health and performance of animals and humans remain unknown. A minimum threshold of $30 \mathrm{ng} / \mathrm{mL}$ to support immune function was proposed based on epidemiological data from human populations but remains hypothetical (Gunville et al., 2013). A recent survey of vitamin D status of dairy cows showed that the majority of lactating cows received 1.5 to 2.5 times the NRC recommendation for supplemental vitamin $\mathrm{D}_{3}$ and had average serum $25(\mathrm{OH}) \mathrm{D}$ concentrations of 60 to $70 \mathrm{ng} / \mathrm{mL}$, ranging between 40 to $100 \mathrm{ng} /$ $\mathrm{mL}$ (Nelson et al., 2016). The broad range in serum $25(\mathrm{OH}) \mathrm{D}$ concentrations in these dairy cattle might be due to metabolic demands that occur during the production cycle and dramatic shifts in DMI (Horst et al., 1994; Ingvartsen and Andersen, 2000; Hayirli et al., 2002). However, limited data exist describing the effects of external influences on serum $25(\mathrm{OH}) \mathrm{D}$ concentrations in dairy cows. The objective of this study was to determine how serum $25(\mathrm{OH}) \mathrm{D}$ concentrations of healthy dairy cattle are affected by season, age, parity, and stage of lactation as dairy cattle transition from dry off to the close-up and early postpartum periods. We hypothesized that serum $25(\mathrm{OH}) \mathrm{D}$ concentrations would be significantly lower in dairy cattle during early lactation compared with dry off and the close-up period. We performed a longitudinal, herd-based epidemiologic investigation of serum $25(\mathrm{OH}) \mathrm{D}$ concentrations in healthy dairy cattle on 5 commercial farms by sampling dairy cattle of varying parities and ages during different seasons and at 3 specific times during the lactation cycle.

\section{MATERIALS AND METHODS}

\section{Animals}

The Animal Use and Care Committee at Michigan State University (East Lansing) approved this study and all animal protocols. A total of 300 cows from 5 commercial dairy herds in Michigan were enrolled. Cohorts containing 15 cows/cohort from each of the 5 farms were included in the study. Cows in the cohorts were selected randomly from the group of animals to be dried off each week and were enrolled based on date of dry off and stage of lactation. Each cohort of 15 cows contained 3 groups of 5 cows per group that included 5 heifers $<25$ mo old, 5 second-lactation cows, and 5 cows that were third or greater lactation. Cows were approximately 200 to $230 \mathrm{~d}$ pregnant and $<380$ DIM at the time of dry-off. All cows were bred by AI to ensure more accurate calving dates. The health status of each cow was monitored from the nonlactating period through the lactation cycle using Dairy COMP305 (Alta Genetics Inc., Watertown, WI) or PCDART (NorthStar Michigan Lab, Grand Ledge, MI) on-farm software. All animal health records were maintained in Dairy COMP305 or PCDART using established treatment protocols so that disease incidence was recorded consistently. Cows diagnosed with mastitis, metritis, ketosis, lameness, displaced abomasum, pneumonia, milk fever, or retained placenta during the first 30 $\mathrm{d}$ of lactation, and cows with other negative health outcomes including abortion and death were excluded from the analysis. Each farm fed a TMR supplemented with vitamin $\mathrm{D}_{3}$ (Table 1 ).

\section{Measurement of 25-Hydroxyvitamin D}

Blood samples were collected from the tail vein at dry off, within $7 \mathrm{~d}$ of entering the close-up group, and within $7 \mathrm{~d}$ of calving (calving +7 ). Sampling interval between close-up and calving +7 was $22.3 \pm 7.5 \mathrm{~d}$ (mean $\pm \mathrm{SD}$ ). Serum was harvested and stored at $-20^{\circ} \mathrm{C}$ for batch analysis of $25(\mathrm{OH}) \mathrm{D}$ for 1 to 6 mo. The metabolite $25(\mathrm{OH}) \mathrm{D}$ is robust and stable when stored in sealed glass or plastic vials at $-20^{\circ} \mathrm{C}$ for up to 48 mo (Ockè et al., 1995). The total concentration of $25(\mathrm{OH}) \mathrm{D}$ (the sum of 25-hydroxyvitamin $\mathrm{D}_{2}$ and 25-hydrovitamin $\mathrm{D}_{3}$ ) in serum samples was measured by RIA by Heartland Assays (Iowa State University Research Park, Ames; Farrell et al., 2012) in singlicates. The detection range of the assay was 2.5 to $100 \mathrm{ng} / \mathrm{mL}$, with analytical sensitivity of $1.5 \mathrm{ng} / \mathrm{mL}$. Analytical specificity based on cross reactivity of other metabolites was $100 \%$ for $25(\mathrm{OH}) \mathrm{D}_{3}, \quad 25(\mathrm{OH}) \mathrm{D}_{2}, \quad 24,25(\mathrm{OH})_{2} \mathrm{D}_{2}, \quad 24,25(\mathrm{OH})_{2} \mathrm{D}_{3}$, $25,26(\mathrm{OH})_{2} \mathrm{D}_{2}, 25,26(\mathrm{OH})_{2} \mathrm{D}_{3}$, and $11 \%$ for $1,25(\mathrm{OH}) \mathrm{D}_{2}$ 
Table 1. Vitamin D (kIU/kg of DM) supplemented in feed by farms for heifers and cows during 2 to 10 DIM, close up, and dry off

\begin{tabular}{|c|c|c|c|c|c|c|}
\hline Farm & \multicolumn{2}{|c|}{ 2-10 DIM } & \multicolumn{2}{|c|}{ Close up ${ }^{1}$} & \multicolumn{2}{|c|}{ Dry off ${ }^{2}$} \\
\hline 1 & 1.67 & 1.67 & 4.40 & 2.73 & 1.78 & 2.2 \\
\hline 3 & 2.42 & 2.42 & 4.38 & 2.87 & 3.96 & 4.38 \\
\hline 4 & 1.45 & 1.45 & 1.45 & 1.45 & 1.45 & 1.45 \\
\hline 5 & 1.32 & 1.32 & 1.32 & 1.32 & 1.32 & 1.32 \\
\hline
\end{tabular}

${ }^{1}$ Close up = approximately $21 \mathrm{~d}$ prepartum.

${ }^{2}$ Dry off $=$ approximately $60 \mathrm{~d}$ prepartum.

and $1,25(\mathrm{OH}) \mathrm{D}_{3}$. The assay has $<0.8 \%$ cross reactivity with vitamin $\mathrm{D}_{2}$ and vitamin $\mathrm{D}_{3}$. The interassay and intraassay coefficients of variation were 13.3 and $6.5 \%$, respectively. The assay trueness was checked by serial dilution and recovery test for linearity (parallelism).

\section{Data Analysis}

Repeated-measures linear mixed-effects models were constructed using the Proc Mixed command in SAS 9.4 (SAS Institute Inc., Cary, NC) to analyze the effects of sample period, age, parity, and season on serum $25(\mathrm{OH})$ D concentrations. Age, parity, and season were treated as categorical fixed effects. Categories for age and parity were created based on the distribution of the data (Table 2). Season was based on what month the samples were collected (March, April, May = spring; June, July, August $=$ summer; September, October, November $=$ fall; December, January, February = winter). Sample period was coded as the average number of days from dry off for each of the 3 sample points, 0 d (dry off), $32 \mathrm{~d}$ (close up), and $55 \mathrm{~d}$ (calving +7 ). The final multivariable linear mixed-effects model was constructed using a backward elimination method, which entailed starting with a loaded mean structure model, selecting the covariance structure for random effects, selecting a residual covariance structure, and then testing the significance of interaction terms and fixed effects (West et al., 2007). Loaded mean structure models include all possible fixed effects and biologically plausible interaction terms. In addition, the loaded model included random intercepts for farm, cohort nested within farm, and cow nested within cohort and farm. To account for unequally distanced sampling points, the best fitting spatial covariance structure was selected based on Akaike's information criterion (smallest) or convergence of the model. Degrees of freedom were estimated using the Kenward-Roger approximation. Random effects of intercepts for farm, cohort, and cow were tested for retention in the model. Random effects and residual covariance structures were tested for significance using likelihood-ratio tests based on REML estimation. The test statistic for testing random effects was a mixture of chi-squared distributions with degrees of freedom of 0 to 1 , and equal weights of 0.5 . Multicollinearity of fixed effects was tested by estimating Spearman correlation coefficients before inclusion in the multivariable model building. Fixed effects and all plausible 2-way interaction terms were selected for inclusion in the model by comparing nested models using likelihood-ratio tests based on maximum likelihood estimation (MLE). Normal distribution of residuals and heteroskedasticity was assessed visually using histograms and Q-Q (quantile-quantile) plots of standardized residuals, and predicted-residual plots. Potential heteroskedasticity of sample period was also tested using a likelihood ratio tests based on REML estimation using the GROUP option in the REPEATED statement. Statistical significance was set at $P<0.05$.

\section{RESULTS}

Three hundred cows were enrolled and blood samples were collected from 283 cows from September 24, 2014, to December 15, 2015. One hundred cows were excluded from the study due to disease at some point during the study. The final study population included data from the remaining 183 cows, 11 of which had incomplete $25(\mathrm{OH}) \mathrm{D}$ data. Ten cows were missing vitamin $\mathrm{D}$ data for the close-up period because these 10 cows calved early. One of 11 cows was missing a $25(\mathrm{OH}) \mathrm{D}$ data point for calving +7 for an unknown reason. Descriptive statistics for $25(\mathrm{OH}) \mathrm{D}$ by parity, age, season, and sample period are shown in Table 2 .

The bivariable analyses that evaluated the effects of parity, season, and age on serum $25(\mathrm{OH}) \mathrm{D}$ concentrations are shown in Table 3. Random intercepts for farm and cow significantly improved model fit $(P<0.01)$ in all 3 bivariable analyses. Cohort did not significantly improve model fit and was not included for parity $(P$ 
Table 2. Descriptive statistics for serum 25-hydroxyvitamin D [25(OH)D] concentrations (ng/mL) by parity, age, season, and sample period $(\mathrm{n}=183 \mathrm{cows})$

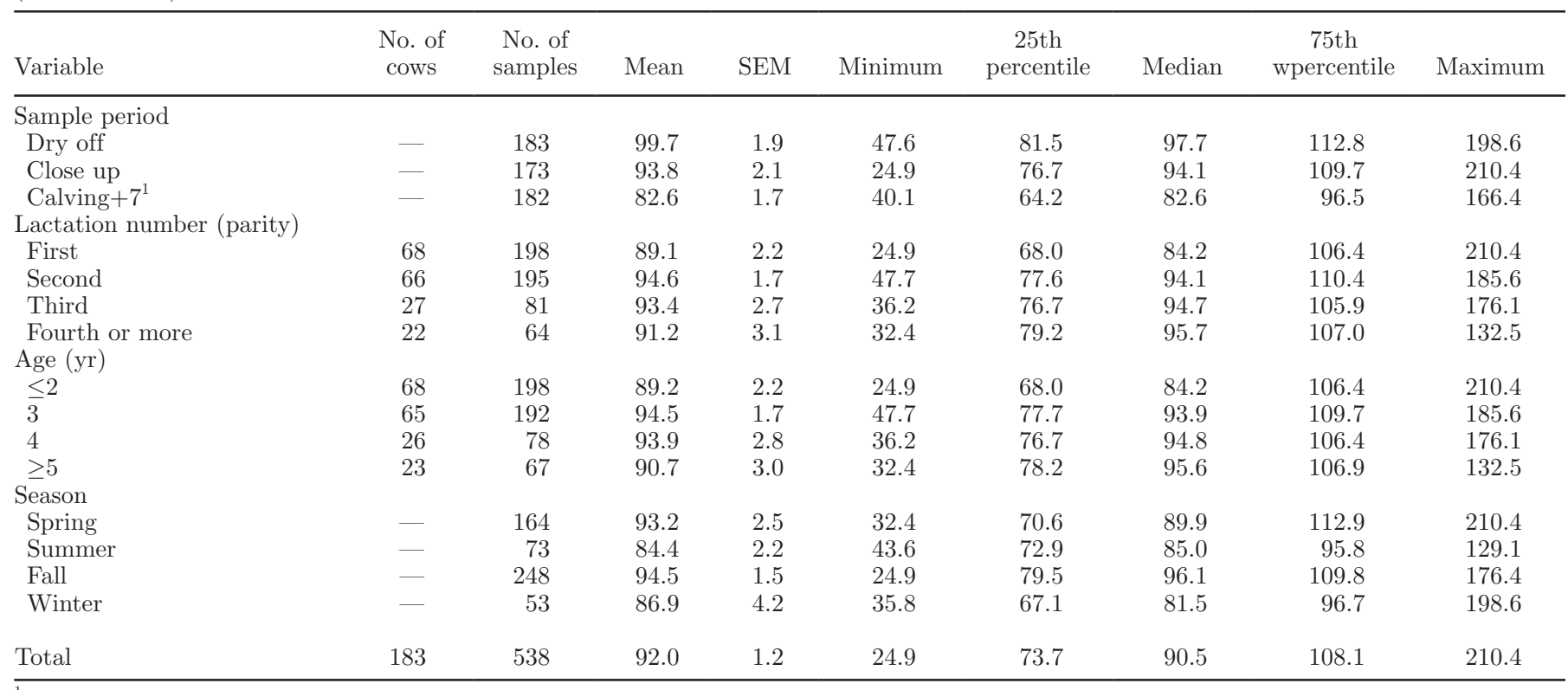

${ }^{1}$ Within $7 \mathrm{~d}$ after calving.

$=0.33)$, season $(P=0.30)$, or age $(P=0.33)$ analyses. Parity, age, and season were not significantly associated with serum $25(\mathrm{OH}) \mathrm{D}$ concentrations $(P=0.26,0.37$, and 0.40 , respectively).
In the multivariable analysis, age was not included due to its high correlation with parity $(\mathrm{r}=0.99)$. The spatial power residual covariance structure was used to account for unequal spacing between sample

Table 3. Summary of bivariable analyses estimating associations between serum 25-hydroxyvitamin D $[25(\mathrm{OH})$

$\mathrm{D}]$ concentrations $(\mathrm{ng} / \mathrm{mL})$ and parity, age, and season

\begin{tabular}{|c|c|c|c|c|c|c|}
\hline \multirow[b]{2}{*}{ Parameter } & \multirow[b]{2}{*}{ Estimate } & \multirow[b]{2}{*}{ SE } & \multicolumn{2}{|c|}{$95 \% \mathrm{CI}$} & \multirow[b]{2}{*}{$P$-value } & \multirow[b]{2}{*}{$\mathrm{ICC}$} \\
\hline & & & Lower & Upper & & \\
\hline Sample period $^{2}$ & -0.30 & 0.03 & -0.36 & -0.24 & $<0.01$ & 0.61 \\
\hline Intercept & 100.49 & 6.44 & 82.91 & 118.07 & $<0.01$ & \\
\hline \multicolumn{7}{|c|}{ Lactation number (parity) ${ }^{3}$} \\
\hline Intercept & 88.89 & 6.00 & 77.14 & 100.65 & 0.26 & 0.53 \\
\hline First (referent) & - & - & - & - & & \\
\hline Second & 5.42 & 3.21 & -0.87 & 11.72 & & \\
\hline Third & 5.65 & 4.26 & -2.70 & 14.00 & & \\
\hline Fourth or more & -0.12 & 4.57 & -9.08 & 8.84 & & \\
\hline \multicolumn{7}{|l|}{ Age $(y r)^{4}$} \\
\hline Intercept & 88.89 & 6.00 & 77.15 & 100.64 & 0.37 & 0.54 \\
\hline$\leq 2$ (referent) & - & - & - & - & & \\
\hline 3 & 5.43 & 3.23 & -0.91 & 11.77 & & \\
\hline 4 & 5.72 & 4.32 & -2.75 & 14.20 & & \\
\hline$\geq 5$ & 0.02 & 4.52 & -8.84 & 8.87 & & \\
\hline \multicolumn{7}{|l|}{ Season $^{5}$} \\
\hline Intercept & 92.15 & 5.74 & 82.86 & 105.37 & 0.40 & 0.54 \\
\hline Spring (referent) & - & - & - & - & & \\
\hline Summer & -2.92 & 2.95 & -8.70 & 2.85 & & \\
\hline Fall & 0.61 & 2.84 & -4.96 & 6.19 & & \\
\hline Winter & -3.41 & 3.50 & -10.27 & 3.44 & & \\
\hline
\end{tabular}

${ }^{1} \mathrm{ICC}=$ intraclass correlation coefficient at the cow-within-farm level.

${ }^{2}$ Final model. Random effect estimates, farm: 193.34 (95\% CI: $66.93,1,867.09$ ), cow: 256.68 (95\% CI: 197.05 , $348.32)$, spatial power 0.53 (95\% CI: $-11.27,12.34)$.

${ }^{3}$ Random intercept estimates, farm: 154.01 (95\% CI: 41.38, 573.19), cow: 224.77 (95\% CI: 163.23, 309.52).

${ }^{4}$ Random intercept estimates, farm: 153.36 (95\% CI: 41.17, 571.26), cow: 227.98 (95\% CI: 165.90, 313.30).

${ }^{5}$ Random intercept estimates, farm: 144.76 (95\% CI: 38.57, 543.30), cow: 234.32 (95\% CI: 171.05, 320.99). 
periods. Inspection of the histograms and Q-Q plots of standardized residuals indicated normality. Similar to the bivariable analyses, random intercepts for farm and cow significantly improved model fit $(P<0.001)$, whereas cohort was excluded because it did not improve the model fit $(P=0.32)$. Parity and season were removed from the model during backward elimination due to a lack of association with serum $25(\mathrm{OH}) \mathrm{D}$ concentrations $(P=0.25$ and $P=0.75$, respectively). Only sample period remained in the final model and it was significant $(P<0.01)$, with the highest serum $25(\mathrm{OH})$ $\mathrm{D}$ concentrations at dry off followed by close up, and the lowest levels being detected at calving +7 (Table 3 ).

\section{DISCUSSION}

The incidence and severity of dairy cattle disease are greatest during the physiologic transition from late gestation to early lactation (Castillo et al., 2005; Sordillo and Raphael, 2013). Disease risk in these cows is associated with increased metabolic pressures and dysfunctional immunity that occur late in pregnancy and during early lactation (Sordillo, 2016). Vitamin D supplementation enhances innate immunity by stimulating the production of pattern recognition receptors, antimicrobial peptides and cytokines by immunologically responsive cells (Dimitrov and White, 2017) and improves metabolic and reproductive profiles in transition dairy cattle (Omur et al., 2016). Vitamin D administration is also associated with diminished oxidative stress by increasing total oxidative capacity in transition water buffaloes with subclinical mastitis (Dimri et al., 2013). Our results showed that serum 25(OH)D concentrations were significantly lower in the transition period during early lactation compared with the closeup and dry-off periods, at a time when dairy cattle are most vulnerable to disease and metabolic stresses. The biological significance of a reduction in serum $25(\mathrm{OH})$ $\mathrm{D}$ concentrations in these healthy dairy cows is unclear and likely negligible. However, diminished serum $25(\mathrm{OH}) \mathrm{D}$ concentrations in transition dairy cattle may enhance oxidative stress and play a role in disease susceptibility. Future studies determining associations between changes in serum $25(\mathrm{OH}) \mathrm{D}$ concentrations and occurrence of transition period diseases and establishing the optimum serum concentrations of $25(\mathrm{OH}) \mathrm{D}$ to support immune function in dairy cattle may be warranted.

Determining the cause of the decrease in serum $25(\mathrm{OH}) \mathrm{D}$ during the transition period was beyond the scope of this study. Likely, the decrement in serum $25(\mathrm{OH}) \mathrm{D}$ concentration was due to increased consumption of vitamin $\mathrm{D}$ metabolites by immunological and calcium homeostatic systems during the early post- partum period. Nelson and colleagues surveyed serum $25(\mathrm{OH}) \mathrm{D}$ in dairy cattle at different stages of lactation and noted that serum $25(\mathrm{OH}) \mathrm{D}$ was lower in earlylactation cows compared with mid- and late-lactation dairy cattle (Nelson et al., 2016). Olsen and colleagues reported that stage of lactation had a significant effect on the serum concentrations of vitamin D binding protein (DBP) and 25(OH)D (Olsen et al., 2016); DBP is bound to $25(\mathrm{OH}) \mathrm{D}$ in circulation. Both $\mathrm{DBP}$ and $25(\mathrm{OH}) \mathrm{D}$ were lowest at the beginning of lactation and increased as lactation progressed (Olsen et al., 2016), suggesting that consumption of these nutrients at parturition led to their depletion.

The total antioxidant potential and many specific antioxidants, including vitamin E, selenium, and ascorbic acid, are depleted during the transition period in dairy cattle (Weiss et al., 1990; Bernabucci et al., 2005; Castillo et al., 2005; Sordillo et al., 2007) supporting the premise that consumption of $25(\mathrm{OH}) \mathrm{D}$ metabolites during early lactation may account for the decrement in serum concentrations. Oxidative stress, an imbalance between the production of reactive oxygen metabolites and antioxidants, occurs during the transition period, leading to antioxidant depletion in an attempt to balance the pro-oxidative status of the cow (Bernabucci et al., 2005; Sordillo et al., 2007). Parturition is an inflammatory event (Bradford et al., 2015). The highest serum concentrations of the acute phase proteins haptoglobin and C-reactive protein were measured in HolsteinFriesian dairy cows within the first postpartum month compared with prepartum and late-lactation samples (Dębski et al., 2016). An inverse correlation was reported between C-reactive protein and $25(\mathrm{OH}) \mathrm{D}$ in humans, with a $40 \%$ decrement in $25(\mathrm{OH}) \mathrm{D}$ when C-reactive protein increased from $<5$ to $>80 \mathrm{mg} / \mathrm{L}$ (Duncan et al., 2012). Systemic inflammatory processes, such as parturition and oxidative stress, reduce serum $25(\mathrm{OH})$ $\mathrm{D}$ concentrations due to intracellular hydroxylation of $25(\mathrm{OH}) \mathrm{D}$ to $1,25(\mathrm{OH})_{2} \mathrm{D}_{3}$, enhancing consumption of vitamin D metabolites (Heaney and Armas, 2015).

Calcium demand by the mammary gland in early lactation overwhelms a cow's ability to maintain normal plasma calcium (Horst et al., 1994). Increased parathyroid hormone reduces urinary calcium losses, stimulates bone calcium resorption, and increases $1,25(\mathrm{OH})_{2} \mathrm{D}_{3}$ synthesis to enhance the active transport of calcium in the intestine. The increase in $1,25(\mathrm{OH})_{2} \mathrm{D}_{3}$ at parturition drives the vitamin $\mathrm{D}$ metabolite degradation pathways, leading to the depletion of serum 25(OH) D concentrations (Horst et al., 1994). Colostrogenesis also consumes 25(OH)D (Horst et al., 2005). Colostrum contains 2 to 3 times as much $25(\mathrm{OH}) \mathrm{D}_{3}$ as samples taken at the sixth milking and 28 DIM (Weiss et al., 2015). The combined effects of these lactation and im- 
mune system events likely caused the decline in serum $25(\mathrm{OH}) \mathrm{D}$ concentrations measured at calving +7 in this study.

Transient renal dysfunction and disruption of renal tubular cells could lead to diminished serum $25(\mathrm{OH})$ $\mathrm{D}$ concentrations in early-lactation cows. Tubular cell dysfunction and alterations in tubular cell proteins can cause excretion of $25(\mathrm{OH}) \mathrm{D} / \mathrm{DBP}$ in the urine, resulting in a lower serum concentration of $25(\mathrm{OH}) \mathrm{D}$ (Anderson et al., 2010). The cows in our study were clinically healthy, making even subclinical kidney dysfunction unlikely. However, subclinical injury might precede kidney dysfunction. Serum creatinine was increased in dairy cattle at parturition compared with 3 wk postpartum (Omur et al., 2016). Increased serum creatinine is indicative of parenchymal injury and kidney dysfunction. In that study, dairy cattle supplemented with antioxidant vitamins, including vitamin $\mathrm{D}$ and trace elements, showed no increase in serum creatinine in postpartum early lactation compared with prepartum measurements, and the creatinine values at parturition in the supplemented cattle were significantly lower than in controls (Omur et al., 2016).

Measurement of individual cow DMI was beyond the scope of this study. The diminished serum $25(\mathrm{OH})$ $\mathrm{D}$ concentrations measured at calving +7 might have been due in part to decreased vitamin D dietary consumption. Substantial decrements in DMI occur in late pregnancy and continue into early lactation in dairy cattle (Ingvartsen and Andersen, 2000). Dry matter intake decreased $32 \%$ during the final $3 \mathrm{wk}$ of gestation, and $89 \%$ of that decline occurred during the final week of gestation (Hayirli et al., 2002). Plasma half-life of $25(\mathrm{OH}) \mathrm{D}_{3}$ in dairy cows is 16 to $32 \mathrm{~d}$ but depends on amount supplemented, parity, and diet (Wilkens et al., 2013).

Dairy cattle in the current study were from 5 commercial Michigan farms located in a latitude range of 43 to $44^{\circ} \mathrm{N}$ and housed largely indoors, limiting their exposure to UV light. Indoor housing was likely responsible for the lack of a measurable season effect of serum $25(\mathrm{OH}) \mathrm{D}$ in the study population. Parity and age were not significantly associated with serum $25(\mathrm{OH}) \mathrm{D}$ concentrations in our study, supporting the results of a large survey of serum $25(\mathrm{OH}) \mathrm{D}$ concentrations in dairy cattle (Nelson et al., 2016).

\section{CONCLUSIONS}

Serum $25(\mathrm{OH}) \mathrm{D}$ concentrations were lowest during early lactation, a time of increased disease susceptibility. The reason for the decrement in serum $25(\mathrm{OH}) \mathrm{D}$ concentrations at calving +7 is unclear but might be due to increased consumption of vitamin $\mathrm{D}$ by immune and calcium homeostatic systems. Establishing associations between serum $25(\mathrm{OH}) \mathrm{D}$ concentrations and transition period diseases is an important next step toward determining optimum $25(\mathrm{OH}) \mathrm{D}$ concentrations to support immune health in dairy cows.

\section{ACKNOWLEDGMENTS}

This research was supported by the USDA National Institute of Food and Agriculture (NIFA, Washington, DC) project (2014-68004-21972), the Michigan State University Endowed Research Funds, and the Michigan Animal Health Foundation.

\section{REFERENCES}

Adams, J. S., and M. Hewison. 2008. Unexpected actions of vitamin D: New perspectives on the regulation of innate and adaptive immunity. Nat. Clin. Pract. Endocrinol. Metab. 4:80-90.

Anderson, R. L., S. B. Ternes, K. A. Stand, and M. J. Rowling. 2010. Vitamin D homeostasis is compromised due to increased urinary excretion of the 25-hydroxycholecalciferaol-vitamin D-binding protein complex in the Zucker diabetic fatty rat. Am. J. Physiol. Endocrinol. Metab. 299:E959-E967.

Bernabucci, U., B. Ronchi, N. Lacetera, and A. Nardone. 2005. Influence of body condition score on relationships between metabolic status and oxidative stress in periparturient dairy cows. J. Dairy Sci. 88:2017-2026.

Bradford, B. J., K. Yuan, J. K. Farney, L. K. Mamedova, and A. J. Carpenter. 2015. Invited review: Inflammation during the transition to lactation: New adventures with an old flame. J. Dairy Sci. 98:6631-6650.

Castillo, C., J. Hernandez, A. Bravo, M. Lopez-Alonso, J. L. Pereira, and V. Benedito. 2005. Oxidative status during late pregnancy and early lactation in dairy cows. Vet. J. 169:286-292.

Dębski, B., T. Nowicki, W. Zalewski, M. Ochota, J. Mrowiec, and J. Twardon. 2016. Evaluation of acute phase proteins in clinically healthy dairy cows in perinatal period and during lactation. Pol. J. Vet. Sci. 19:519-523.

Dimitrov, V., and J. H. White. 2017. Vitamin D signaling in intestinal innate immunity and homeostasis. Mol. Cell. Endocrinol. 453:68-78.

Dimri, U., M. C. Sharma, S. K. Singh, P. Kumar, R. Jhambh, B. Singh, S. Bandyopadhyay, and M. R. Verma. 2013. Amelioration of altered oxidant/antioxidant balance of Indian water buffaloes with subclinical mastitis by vitamins $\mathrm{A}, \mathrm{D}_{3}, \mathrm{E}$ and $\mathrm{H}$ supplementation. Trop. Anim. Health Prod. 45:971-978.

Duncan, A., D. Talwaar, D. C. McMillan, F. Stefanowicz, and D. S. O'Reilly. 2012. Quantitative data on the magnitude of the systemic inflammatory response and its effect on micronutrient status based on plasma measurement. Am. J. Clin. Nutr. 95:64-71.

Farrell, C. J., S. Martin, B. McWhinney, I. Straub, P. Williams, and M. Herrmann. 2012. State-of-the-art vitamin D assays: A comparison of automated immunoassays with liquid chromatographytandem mass spectrometry methods. Clin. Chem. 58:531-542.

Girard, A., I. Dufort, and M. A. Sirard. 2015. The effect of energy balance on the transcriptome of bovine granulosa cells at 60 days postpartum. Theriogenology 84:1350-1361.

Gunville, C. F., P. M. Mourani, and A. A. Ginde. 2013. The role of vitamin $\mathrm{D}$ in prevention and treatment of infection. Inflamm. Allergy Drug Targets 12:239-245.

Hayirli, A., R. R. Grummer, E. V. Nordheim, and P. M. Crump. 2002 Animal and dietary factors affecting feed intake during the prefresh transition period in Holsteins. J. Dairy Sci. 85:3430-3443.

Heaney, R. P., and L. A. Armas. 2015. Quantifying the vitamin D economy. Nutr. Rev. 73:51-67. 
Horst, R. L., J. P. Goff, and T. A. Reinhardt. 1994. Calcium and vitamin D metabolism in the dairy cow. J. Dairy Sci. 77:1936-1951.

Horst, R. L., J. P. Goff, and T. A. Reinhardt. 2005. Adapting to the transition between gestation and lactation: differences between rat, human, and dairy cow. J. Mammary Gland Biol. Neoplasia 10:141-156.

Hymøller, L., and S. K. Jensen. 2010. Vitamin $\mathrm{D}_{3}$ synthesis in the entire skin surface of dairy cows despite hair coverage. J. Dairy Sci. 93:2025-2029.

Hymøller, L., and S. K. Jensen. 2012. 25-Hydroxycholecalciferol status in plasma is linearly correlated to daily summer pasture time in cattle at $56^{\circ} \mathrm{N}$. Br. J. Nutr. 108:666-671.

Ingvartsen, K. L., and J. B. Andersen. 2000. Symposium: Dry matter intake of lactating dairy cattle. J. Dairy Sci. 83:1573-1597.

Lippolis, J. D., T. A. Reinhardt, R. A. Sacco, B. J. Nonnecke, and C. D. Nelson. 2011. Treatment of an intramammary bacterial infection with 25-hydroxyvitamin D3. PLoS One 6:e25479. https://doi .org/10.1371/journal.pone.0025479.

Nelson, C. D., J. D. Lippolis, T. A. Reinhardt, R. E. Sacco, J. L. Powell, M. E. Drewnoski, M. O'Neil, D. C. Beitz, and W. P. Weiss. 2016. Vitamin D status of dairy cattle: Outcomes of current practices in the dairy industry. J. Dairy Sci. 99:10150-10160.

Nelson, C. D., T. A. Reinhardt, J. D. Lippolis, R. E. Sacco, and B. J. Nonnecke. 2012. Vitamin D signaling in the bovine immune system: A model for understanding human vitamin D requirements. Nutrients 4:181-196.

Nelson, C. D., T. A. Reinhardt, T. C. Thacker, D. C. Beitz, and J. D. Lippolis. 2010. Modulation of the bovine innate responses by production of $1 \alpha, 25$-dihydroxyvitamin $\mathrm{D}_{3}$ in bovine monocytes. J. Dairy Sci. 93:1041-1049.

NRC. 2001. Nutrient Requirements of Dairy Cattle. 7th rev. ed. Natl. Acad. Press, Washington, D.C.

Ockè, M. C., J. Shrijver, G. L. Obermann-De Boer, B. P. Bloemberg, G. R. Haenen, and D. Kromhout. 1995. Stability of blood (pro) vitamins during 4 years of stage at $-20^{\circ} \mathrm{C}$ : Consequences for epidemiologic research. J. Clin. Epidemiol. 48:1077-1085.

Olsen, H. G., T. M. Knutsen, A. M. Lewandowska-Sabat, H. Grove, T. Nome, M. Svendsen, M. Arnyasi, M. Sodeland, K. Sundsaasen, S. R. Dahl, B. Heringstad, H. H. Hansen, I. Olsaker, M. P. Kent, and S. Lien. 2016. Fine mapping of a QTL on bovine chromosome
6 using imputed full sequence data suggests a key role for the group-specific component (GC) gene in clinical mastitis and milk production. Genet. Sel. Evol. 48:79-92.

Omur, A., A. Kirbas, E. Aksu, F. Kandemir, E. Dorman, O. Kaynar, and O. Ucar. 2016. Effects of antioxidant vitamins (A, D, E) and trace elements $(\mathrm{Cu}, \mathrm{Mn}, \mathrm{Se}, \mathrm{Zn})$ on some metabolic and reproductive profiles in dairy cows during transition period. Pol. J. Vet. Sci. 19:697-706.

Sordillo, L. M. 2016. Nutritional strategies to optimize dairy cattle immunity. J. Dairy Sci. 99:4967-4982.

Sordillo, L. M., N. O'Boyle, J. C. Gandy, C. M. Corl, and E. Hamilton. 2007. Shifts in thioredoxin reductase activity and oxidant status in mononuclear cells obtained from transition dairy cattle. J. Dairy Sci. 90:1186-1192.

Sordillo, L. M., and W. Raphael. 2013. Significance of metabolic stress, lipid mobilization, and inflammation on transition cow disorders. Vet. Clin. North Am. Food Anim. Pract. 29:267-278.

Spears, J. W. and W. P. Weiss. 2008. Role of antioxidants and trace elements in health and immunity of transition dairy cows. Vet. J. 176:70-76.

Téllez-Pérez, A. D., N. Alva-Murillo, A. Ochoa-Zarzosa, and J. E. López-Meza. 2012. Cholecalciferol (vitamin D) differentially regulates antimicrobial peptide expression in bovine mammary epithelial cells: Implications during Staphylococcus aureus internalization. Vet. Microbiol. 160:91-98.

Weiss, W. P., E. Azem, W. Steinberg, and T. A. Reinhardt. 2015. Effect of feeding 25-hydroxyvitamin $\mathrm{D}_{3}$ with a negative cation-anion difference diet on calcium and vitamin D status of periparturient cows and their calves. J. Dairy Sci. 98:5588-5600.

Weiss, W. P., J. S. Hogan, K. L. Smith, and K. H. Hoblet. 1990. Relationships among selenium, vitamin E, and mammary gland health in commercial dairy herds. J. Dairy Sci. 73:381-390.

West, B. T., K. B. Welch, and A. T. Galecki. 2007. Linear Mixed Models: A Practical Guide Using Statistical Software. Chapman and Hall/CRC, Boca Raton, FL.

Wilkens, M. R., I. Cohrs, A. L. Lifschitz, D. R. Fraser, K. Olszewski, B. Schroder, and G. Breves. 2013. Is the metabolism of 25-hydroxyvitamin $\mathrm{D}_{3}$ age-dependent in dairy cows? J. Steroid Biochem. Mol. Biol. 136:44-46. 